\title{
ANALISIS BAURAN PEMASARAN YANG MEMPENGARUHI KEPUTUSAN PEMBELIAN BAJU DI BEBERAPA DEPARTMENT STORE DI KOTA MALANG
}

Tria Warsa Enggal*, Mochamad Bukhori, Dwiyani Sudaryanti

PPS STIE ASIA, Sekolah Tinggi IImu Ekonomi Asia Malang, Universitas Islam Malang

\section{INFO ARTIKEL}

DOI: 10.32812/jibeka.v13i2.116

ISSN-P: 0126-1258

ISSN-E: 2620-875X

Keywords: Marketing mix, Buying decision, Department store

\begin{abstract}
This study aimed to investigate the effect between the marketing mix components; Product, Price, Promotion, and Place on the Buying decision of clothing consumers at the selected department stores in Malang City. The population in this study was all the clothing consumers at the selected department stores in Malang City. Sampling was done by Proportional random sampling technique, and obtained the sample of 150 respondents. Primary data was collected using questionnaire as the research instrument. Data analysis was performed using Multiple Linear Regression analysis on the SPSS 21 program. The results validated that Products, Price, Promotion, and Place have a significant effect on the consumers' buying decision. This is showed by the significance value both in partial and simultaneous test. The influence of all components of the marketing mix on the consumers' buying decision is $50.3 \%$. In addition, the component of marketing mix with the biggest influence is promotion. Therefore, it can be concluded that the marketing mix has a significant effect on the buying decision of clothing consumers of department stores in Malang City.
\end{abstract}

\section{ABSTRAK}

Penelitian ini bertujuan untuk mengkaji pengaruh parsial maupun simultan antara komponen bauran pemasaran, yakni produk, harga, promosi, dan tempat terhadap keputusan pembelian pada konsumen baju di department store terpilih di Kota Malang. Populasi dalam penelitian ini adalah seluruh konsumen yang membeli baju di department store terpilih di Kota Malang. Pengambilan sampel dilakukan dengan teknik Proportional random sampling, dan diperoleh sampel penelitian sebanyak 150 responden. Data primer dikumpulkan dengan menggunakan kuesioner sebagai instrumen penelitian. Analisis data dilakukan dengan menggunakan uji Regresi Linier Berganda dengan bantuan program SPSS 21. Hasil penelitian menunjukkan bahwa produk, harga, promosi, dan tempat terbukti memiliki pengaruh yang signifikan terhadap keputusan pembelian. Hal ini ditunjukkan dengan nilai signifikansinya baik pada pengujian secara parsial maupun simultan. Besar pengaruh dari seluruh komponen bauran pemasaran terhadap keputusan pembelian adalah sebesar 50,3\%. Adapun komponen bauran yang memiliki pengaruh terbesar adalah promosi. Dengan demikian, maka dapat disimpulkan bahwa bauran pemasaran memiliki pengaruh yang signifikan terhadap keputusan pembelian baju di department store di Kota Malang. 


\section{Pendahuluan}

Departement store merupakan salah satu industri ritel yang kini semakin diminati oleh konsumen untuk berbelanja berbagai kebutuhan sandang. Hal tersebut dikarenakan department store memiliki kelebihan di mana konsumen dapat leluasa memilih barangbarang sesuai dengan selera dan kebutuhannya. Saat ini, department store dihadapkan dengan banyaknya tantangan seiring dengan semakin banyaknya pesaing dan semakin gencarnya online shop dengan berbagai keunggulannya. Kedua hal ini dinilai sebagai penyebab berkurangnya pengunjung departement store. Selain itu, yang tidak kalah menantang adalah biaya operasional yang semakin lama semakin meningkat. Tujuan awal suatu perusahaan didirikan yaitu untuk mendapatkan hasil yang optimal dan keuntungan yang sebanyak-banyaknya. Sehingga, untuk dapat berkembang, perusahaan harus mampu meningkatkan penjualan yang merupakan ujung tombak bisnis. Dengan kata lain, perusahaan harus memperhatikan aspek-aspek bauran pemasaran.

Bauran pemasaran merupakan seperangkat alat pemasaran terkontrol yang dipadukan oleh perusahaan untuk menghasilkan respon yang diinginkan pasar tertuju (Kotler dan Armstrong, 2012). Komponen bauran pemasaran dikenal dengan istilah 4P, yaitu produk (product), harga (price), tempat (place), dan promosi (promotion). Seiring dengan perkembangan zaman, jumlah komponen bauran pemasaran berkembang menjadi tujuh, yakni produk, harga, promosi tempat, orang (personel), proses dan bukti fisik. Adapun penelitian ini mengkaji bauran pemasaran dengan 4P. Menurut Swastha dan Irawan (2002), produk adalah suatu sifat yang kompleks baik dapat diraba maupun tidak dapat diraba, termasuk bungkus, warna, harga, prestise perusahaan dan pengecer, pelayanan perusahaan dan pengecer, yang diterima oleh pembeli untuk memuaskan keinginan atau kebutuhan. Produk yang dijual di department store adalah berbagai kebutuhan sandang, aksesoris, perlengkapan kecantikan, hingga perlengkapan rumah. Beberapa kelebihan berbelanja produk di department store adalah barang yang ditawarkan dianggap lebih berkualitas dan lebih bergengsi, selain itu konsumen bisa dengan mudah memilih dan mencoba langsung barang yang diinginkan.

Promosi meliputi semua kegiatan yang dilakukan perusahaan untuk mengkomunikasikan dan mempromosikan produknya kepada pasar sasaran (Kotler dan Amstrong, 2008). Berbagai cara promosi dilakukan oleh pengusaha department store untuk mengajak konsumen agar berbelanja di tempatnya, baik melalui website, media sosial, media cetak, dan media elektronik. Hal tersebut bertujuan untuk menarik perhatian konsumen meskipun untuk itu perusahaan harus mengeluarkan biaya yang besar. Selanjutnya, harga adalah sejumlah uang yang dibutuhkan untuk mendapatkan sejumlah kombinasi dari produk dan pelayanannya (Engel dan Blackwell, 2004). Harga adalah satusatunya unsur dalam bauran pemasaran yang akan mendatangkan laba bagi perusahaan, sehingga perusahaan harus memperhatikan besar kecilnya harga yang ditetapkan karena sangat mempengaruhi daya saing dengan kompetitor dan mempengaruhi minat konsumen. Selain itu, faktor lain yang perlu diperhatikan bagi department store adalah tempat. Menurut Lupiyoadi (2013), lokasi dan suasana toko berhubungan dengan kenyamanan bagi pengunjung dan dapat mempengaruhi suasana pada diri konsumen ketika memilih produk. Suasana tersebut dapat mendatangkan reaksi emosi dari konsumen serta merupakan bagian dari kesan akhir setelah mengunjungi toko. 
Penelitian terdahulu yang dilakukan oleh Oktavita (2013) menemukan hasil bahwa bauran pemasaran secara simultan memiliki pengaruh yang signifikan terhadap variabel Struktur Keputusan Pembelian dengan pengaruh sebesar $50 \%$. Selain itu, Tumbel dan Paulina (2015) memperoleh kesimpulan penelitian bahwa Harga, Lokasi, Keragaman Produk, dan Kualitas Produk berpengaruh positif dan signifikan secara parsial terhadap keputusan pembelian konsumen di Pasar Tradisional Kota Manado. Di wilayah Kabupaten Malang sendiri, Masyithoh (2017) melakukan penelitian di Kota Batu dan memperoleh hasil bahwa produk, harga, lokasi dan promosi secara parsial berpengaruh signifikan terhadap keputusan pembelian madu. Temuan ini turut dikuatkan oleh Marendra (2018), bahwa komponen bauran pemasaran berpengaruh signifikan terhadap keputusan pembelian. Secara keseluruhan, hasil penelitian terdahulu menunjukkan temuan empiris yang seragam. Untuk itu, perlu dilakukan penelitian yang lebih mendalam untuk mengkaji kontribusi bauran pemasaran pada konsumen department store Di Kota Malang. Penelitian ini bertujuan untuk mengetahui pengaruh dari komponen bauran pemasaran (produk, harga, promosi, dan tempat) terhadap keputusan pembelian baju di department store yang tersebar di kota Malang.

\section{Metode Penelitian}

Penelitian ini menggunakan metode kuantitatif dengan populasi yaitu pengunjung di beberapa department store yang terdapat di Kota Malang. Penulis memilih penelitian di department store karena menurut pengamatan sementara penulis untuk pembelian baju konsumen di Malang banyak yang memilih membeli di departement store. banyaknya department store di kota Malang, banyaknya pengunjung serta banyak penerapan elemenelemen bauran pemasaran di departement store. Daftar department store yang dipilih sebagai lokasi penelitian adalah sebagai berikut:

Tabel 1. Department Store di Kota Malang

\begin{tabular}{cll}
\hline No & \multicolumn{1}{c}{ Nama Pusat Perbelanjaan } & \multicolumn{1}{c}{ Alamat } \\
\hline 1 & Ramayana Department Store & Jalan Merdeka Timur \\
\hline 2 & Matahari Department Store ex mitra & Jalan KH Agus Salim \\
\hline 3 & Variety Department Store / Malang Plaza & Jalan KH Agus Salim \\
\hline 4 & Center Point (Mall Olimpic Garden) & Jalan Kawi \\
\hline 5 & Trend Departement Store & Jalan S Wiryopranoto \\
\hline
\end{tabular}

Dari populasi responden yang terdapat di lokasi penelitian tersebut, peneliti mengambil sampel sebanyak 150 responden yang ditentukan dengan metode Accidental sampling. Komposisi pembagian sampel didasarkan dari banyaknya jumlah pengunjung dari setiap objek yang diteliti, berdasarkan pengamatan komposisi pembagian sampel penelitian sebagai berikut:

1. Center Point Departement Store

2. Ramayana Department Store

3. Variety Department Store

4. Matahari Departement Store

5. Trend Department Store Jumlah Sampel
$20 \% \times 150=30$
$20 \% \times 150=30$
$20 \% \times 150=30$
$20 \% \times 150=30$
$20 \% \times 150=30$ 
Jenis data yang diteliti adalah data primer, yakni data yang diperoleh langsung dari responden melalui kuesioner yang disebar oleh peneliti. Selanjutnya data penelitian dianalisis dengan metode analisis Regresi Linier Berganda pada program SPSS 21. Uji regresi linear berganda merupakan analisis statistik yang dilakukan untuk mengetahui adanya pengaruh dua atau lebih satu variabel independent terhadap variabel dependen (Sugiyono, 2007). Secara umum, persamaan regresi menurut Sudjana (2003) adalah berikut:

$$
Y=a+b 1 X_{1}+b 2 X_{2}+b 3 X_{3}+b 4 X_{4} \ldots b n X_{n} e
$$

Sebelum dilakukan pengujian hipotesis, baik secara parsial maupun simultan, dilakukan uji asumsi klasik yang meliputi uji Normalitas, Multikolineritas, Heteroskedastisitas, dan uji Linearitas. Adapun analisis Regresi digunakan untuk membuktikan hipotesis penelitian sebagai berikut:

$\mathrm{H} 1$ : Produk (X1) berpengaruh positif terhadap keputusan pembelian baju

H2 : Harga (X2) berpengaruh positif terhadap keputusan pembelian baju

H3 : Promosi (X3) berpengaruh positif terhadap keputusan pembelian baju

H4 : Tempat (X4) berpengaruh positif terhadap keputusan pembelian baju

H5 : Produk, harga, tempat, dan promosi berpengaruh positif terhadap keputusan pembelian baju.

Sehingga, kerangka konseptual dalam penelitian ini dapat digambarkan sebagai berikut:

Gambar 1. Kerangka konsep penelitian

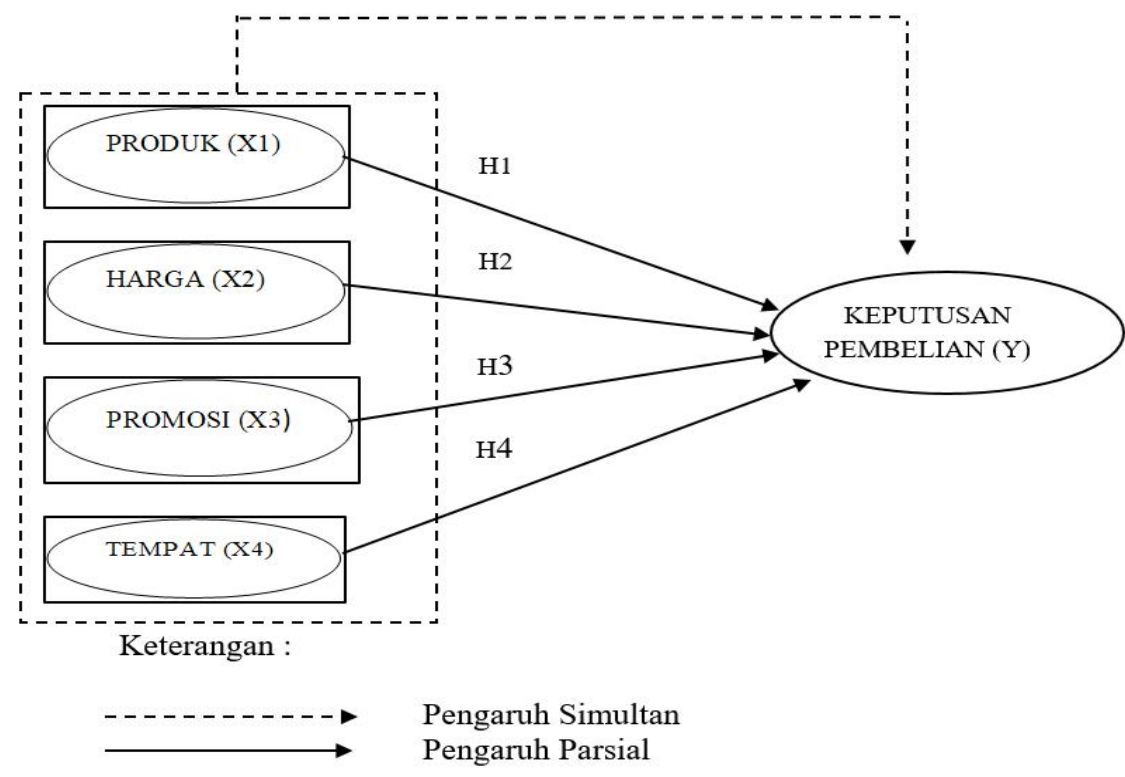

\section{Hasil Penelitian dan Pembahasan}

Pengerjaan analisis Regresi Linier Berganda diawali dengan uji asumsi klasik yang meliputi uji Normalitas, Multikolineritas, Heteroskedastisitas, dan uji Linearitas. Secara 
singkat, hasil pengujian normalitas data dan asumsi klasik menunjukkan bahwa data penelitian berdistribusi normal dan tidak terdapat masalah multikolinearitas, homokedastisitas, dan linearitas. Sehingga dapat dinyatakan bahwa seluruh asumsi klasik telah terpenuhi dan dapat dilanjutkan analisis Regresi.

\section{Persamaan Regresi}

Hasil analisis Regresi ditampilkan melalui tabel berikut:

Tabel 2. Hasil Regresi Linier Berganda

\begin{tabular}{|c|c|c|c|c|c|}
\hline & Unstanda & Coefficients & Standardized Coefficients & & \\
\hline Miodel & $\mathrm{B}$ & Std. Error & Beta & $\mathbf{t}$ & Sig. \\
\hline (Constant) & 3.743 & .700 & & 5.345 & .000 \\
\hline Produk & .228 & .089 & 186 & 2.562 & .011 \\
\hline 1 Harga & .255 & .088 & 212 & 2.907 & .004 \\
\hline Promosi & .198 & .044 & .334 & 4.523 & .000 \\
\hline Tempat & 141 & .065 & .163 & 2.188 & .030 \\
\hline
\end{tabular}

Berdasarkan hasil analisis tersebut, maka dapat dirumuskan persamaan regresi sebagai berikut:

$$
Y=3.743+0.228 X 1+0.255 X 2+0.198 \times 3+0.141 X 4+0.700
$$

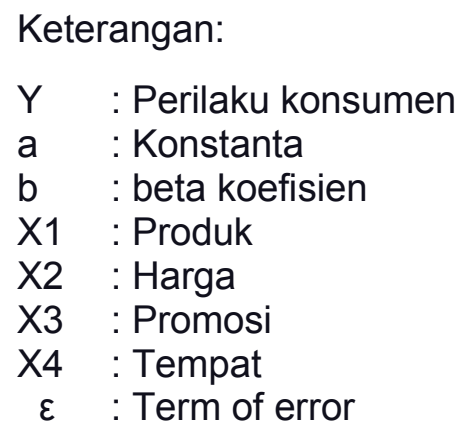

Hasil analisis menunjukkan nilai konstanta sebesar 3.743. Artinya, meskipun tidak dilakukan penelitian seputar informasi bauran pemasaran, keputusan pembelian konsumen telah memiliki nilai pengaruh sebesar 3.743 jika diasumsikan variabel bauran pemasaran, baik itu produk, harga, lokasi, promosi bernilai 0 . Secara spesifik, hasil analisis Regresi akan dijelaskan sesuai sub-bagiannya masing-masing.

\section{Uji Pasial (Uji-t)}

Uji t dalam analisis Regresi digunakan untuk menguji pengaruh masing-masing variabel bebas secara sendiri-sendiri (parsial) terhadap variabel terikat. Pengambilan keputusan atas diterima atau tidaknya hipotesis penelitian adalah dengan melihat nilai signifikansi ( $p$-value) dari masing-masing pengaruh antar variabel bebas terhadap variabel terikat. Taraf nyata $(\alpha)$ yang digunakan adalah 0,05 (5\%). Berikut disajikan hasil uji parsial dari variabel produk, harga, promosi, dan tempat terhadap keputusan pembelian:

Tabel 4. Hasil Uji t

\begin{tabular}{lcl}
\hline Model & $\mathbf{t}$ & Sig. \\
\hline (Constant) & 5.345 & .000 \\
Produk & 2.562 & .011 \\
Harga & 2.907 & .004 \\
Promosi & 4.523 & .000 \\
Tempat & 2.188 & .030 \\
\hline
\end{tabular}


Interpretasi dari hasil uji parsial dapat dijelaskan sebagai berikut:

1. Uji parsial antara variabel Produk terhadap variabel Keputusan Pembelian didapatkan nilai $t$ hitung $(2,562)$ lebih dari t tabel $(1,976)$ atau nilai signifikansi $(0,011)$ kurang dari alpha $(0,050)$. Artinya, terdapat pengaruh positif dan signifikan antara variabel Produk terhadap variabel Keputusan Pembelian. Dengan demikian, maka hipotesis ( $\mathrm{H} 1)$ diterima.

2. Variabel Harga memperoleh nilai $t$ hitung $(2,907)$ lebih dari $t$ tabel $(1,976)$ atau nilai signifikansi $(0,004)$ kurang dari alpha $(0,050)$, sehingga terdapat pengaruh positif dan signifikan antara variabel Harga terhadap variabel Keputusan Pembelian. Dengan demikian, maka hipotesis $(\mathrm{H} 2)$ diterima.

3. Variabel Promosi terhadap variabel Keputusan Pembelian menunjukkan nilai $t$ hitung $(4,523)$ lebih dari t tabel $(1,976)$ atau nilai signifikansi $(0,000)$ kurang dari alpha $(0,050)$, sehingga terdapat pengaruh positif dan signifikan antara variabel Promosi terhadap variabel Keputusan Pembelian. Dengan demikian, maka hipotesis $(\mathrm{H} 3)$ diterima.

4. Uji parsial antara variabel Tempat terhadap variabel Keputusan Pembelian didapatkan nilai t hitung $(2,118)$ lebih dari t tabel $(1,976)$ atau nilai signifikansi $(0,030)$ kurang dari alpha $(0,050)$. Artinya, terdapat pengaruh positif dan signifikan antara variabel Tempat terhadap variabel Keputusan Pembelian. Dengan demikian, maka hipotesis $(\mathrm{H} 4)$ diterima.

\section{Uji Simultan (Uji-F)}

Berikut disajikan hasil pengujian pengaruh antara Produk, Harga, dan Promosi terhadap Keputusan Pembelian secara simultan dengan menggunakan uji $\mathrm{F}$ dalam Tabel 3.

Tabel 3. Hasil Uji Simultan (Uji F)

\begin{tabular}{|c|c|c|c|c|c|c|}
\hline & Model & Sum of Squares & df & Mean Square & $F$ & Sig. \\
\hline \multirow{3}{*}{1} & Regression & 222.163 & 4 & 55.541 & 36.735 & $.000^{\mathrm{b}}$ \\
\hline & Residual & 219.230 & 145 & 1.512 & & \\
\hline & Total & 441.393 & 149 & & & \\
\hline
\end{tabular}

Uji simultan digunakan untuk mengetahui pengaruh variabel independen, yakni produk, harga, promosi dan tempat secara bersama-sama terhadap keputusan pembelian konsumen. Atau secara statistik, digunakan untuk mengetahui apakah model regresi dapat digunakan untuk memprediksi variabel dependent atau tidak. Berdasarkan hasil uji simultan, didapatkan nilai $F$ hitung $(36,735)$ lebih dari $F$ tabel $(2,434)$, dengan nilai signifikansi $(0,000)$ kurang dari alpha $(0,050)$. Dengan demikian, maka dapat dinyatakan bahwa produk, harga, promosi dan tempat secara bersama-sama memiliki pengaruh yang signifikan terhadap Keputusan Pembelian konsumen. Dengan kata lain, Hipotesis $(\mathrm{H} 5)$ penelitian ini diterima.

\section{Koefisien Determinasi}

Tabel 4 menyajikan koefisien determinasi (R2) yang diperoleh dari analisis Regresi. Koefisien determinasi merepresentasikan besar pengaruh dari variabel independen (Produk, Harga, Promosi, dan Tempat) terhadap variabel dependen yaitu keputusan pembelian konsumen. 
Tabel 4. Hasil Koefisien Determinasi

\begin{tabular}{crrrr}
\hline Model & R & R Square & Adjusted R Square & Std. Error of the Estimate \\
\hline 1 & $.709^{a}$ & .503 & .490 & 1.22961 \\
\hline
\end{tabular}

Berdasarkan hasil koefisien determinasi didapatkan nilai $\mathrm{R}$ Square pengaruh bauran pemasaran adalah sebesar 0,503 artinya kemampuan model dalam menjelaskan variasi perubahan variabel Produk, Harga, Promosi, dan Tempat adalah sebesar 50,3\% sedangkan besar pengaruh terhadap variabel Keputusan Pembelian yang ditimbulkan oleh faktor lain adalah sebesar 49,7\%. Penelitian ini menggunakan beberapa variabel independen, sehingga besar pengaruh akan lebih tepat bila dilihat dari nilai Adjusted $R$ Square (koefisien determinasi yang telah disesuaikan). Nilai ini selalu lebih kecil dari $\mathrm{R}$ Square dan bisa memiliki nilai negatif. Menurut Santoso (2001), untuk regresi dengan lebih dari dua variabel bebas, digunakan Adjusted R2 Sebagai koefisien determinasi. Selanjutnya, Ghozali (2001) menambahkan bahwa setiap penambahan satu variabel independen, maka R2 pasti akan meningkat. Oleh karena itu, dianjurkan menggunakan adjusted R2 pada saat mengevaluasi mana model regresi terbaik.

Pengaruh Produk terhadap keputusan pembelian dalam penelitian ini terdiri dari desain dan merk baju ditunjukkan dari hasil deskripsi produk. Desain baju yang mempengaruhi pembelian adalah desain baju yang mengikuti fashion terakhir dan selera konsumen, sedangkan merk baju mempengaruhi pembelian karena berkaitan dengan gengsi konsumen dan loyalitas konsumen terhadap suatu merk. Hal ini didukung dari analisa karakteristik responden alasan memilih department store karna koleksinya yang berkualitas, bervariasi dan up to date. Dari hasil regresi uji linier berganda nilai koefisien produk berpengaruh terhadap keputusan pembelian sebesar 0.228. Nilai tersebut merupakan angka dari beta koefisien yang menunjukkan setiap peningkatan nilai variabel produk (design dan merk baju) sebesar 1 satuan akan mempengaruhi nilai keputusan pembelian sebesar 0.228 atau semakin baik produk maka semakin baik Keputusan Pembelian. Hal ini membuktikan hipotesis 1 tentang produk dapat memberikan pengaruh positif terhadap keputusan pembelian baju dapat diterima. Hasil penelitian dari penelitian ini mendukung hasil penelitian Oktavita (2013) yang menyatakan bahwa variabel Produk (X1), mempunyai pengaruh yang signifikan terhadap variabel Keputusan Pembelian (Y). Selain itu, penelitian ini juga mendukung penelitian Masyithoh (2017) yang juga menyatakan produk setelah diuji secara parsial berpengaruh secara signifikan terhadap keputusan pembelian dengan nilai $t$ hitung yang lebih besar dari t tabel.

Harga yang sesuai perlu untuk ditetapkan karena harga berkaitan erat dengan daya beli konsumen. Harga yang mempengaruhi keputusan pembelian dalam penelitian ini adalah harga yang dapat bersaing dan harga yang terjangkau Hal ini didukung dengan analisis karakteristik responden yang sebagian besar adalah pelajar atau mahasiswa memilih department store karena harganya yang terjangkau dan alasan lainnya membeli baju karena harganya yang murah. Dari hasil uji Regresi linier berganda, nilai koefisien harga berpengaruh terhadap keputusan pembelian sebesar 0.255 menunjukkan setiap peningkatan nilai variabel harga (daya saing harga dan harga yang terjangkau) sebesar 1 satuan akan mempengaruhi nilai keputusan pembelian sebesar 0.255 atau semakin naik harga maka semakin baik keputusan pembelian. Hal ini bisa di mungkinkan karena sebagaian konsumen tidak mempermasalahkan harga karena lebih mempertimbangkan gengsi, mereka bahkan membeli produk baju di department store yang besar dan ternama di 
Malang. Hal ini juga membuktikan hipotesis 2 tentang harga dapat memberikan pengaruh positif terhadap keputusan pembelian baju dapat diterima. Hasil penelitian ini mendukung hasil penelitian Oktavita (2013) yang menyatakan secara parsial harga memiliki pengaruh yang signifikan terhadap Struktur Keputusan Pembelian. Selain itu, penelitian ini juga mendukung penelitian Masyithoh (2017) yang juga menyatakan harga setelah diuji secara parsial berpengaruh secara signifikan terhadap keputusan pembelian dengan nilai $t$ hitung yang lebih besar dari $t$ tabel.

Promosi berkaitan erat dengan media yang sering digunakan oleh konsumen. Pemilihan media promosi yang tepat akan mempengaruhi keputusan pembelian. Hal ini juga didukung hasil analisa karakteristik responden bahwa responden mengetahui asal informasi dari Koran, majalah, serta radio dan televisi. Dari hasil uji regresi linier berganda nilai koefisien promosi berpengaruh terhadap keputusan pembelian sebesar 0.198 menunjukkan setiap peningkatan nilai variabel promosi sebesar 1 satuan akan mempengaruhi nilai Keputusan Pembelian sebesar 0.198 atau semakin baik promosi maka semakin baik keputusan pembelian. Hal ini membuktikan hipotesis 3 tentang promosi dapat memberikan pengaruh positif terhadap keputusan pembelian baju dapat diterima. Hasil penelitian dari penelitian ini mendukung hasil penelitian Oktavita (2013) yang menyatakan bahwa Promosi memiliki pengaruh yang signifikan terhadap Struktur Keputusan Pembelian. Selain itu, penelitian ini juga mendukung penelitian Masyithoh (2017) yang juga menyatakan setelah diuji secara parsial promosi berpengaruh secara signifikan terhadap keputusan pembelian dengan nilai $\mathrm{t}$ hitung yang lebih besar dari t tabel.

Pengaruh tempat terhadap keputusan pembelian dalam penelitian ini terdiri dari kemudahan akses, kebersihan department store dan kenyamanan departement store. Semakin mudah akses department store maka akan semakin sering konsumen berkunjung dan semakin besar kemungkinan membeli baju, semakin bersih dan semakin nyaman department store semakin betah konsumen berada di department store dan semakin besar kemungkinan membeli. Hasil analisis karakteristik responden, department store dipilih karena lokasinya yang dekat dan tempatnya yang nyaman. Dari hasil uji regresi linier berganda nilai koefisien tempat berpengaruh terhadap keputusan pembelian sebesar 0.141 menunjukkan setiap peningkatan nilai variabel tempat (akses ke departement store, kebersihan dan kenyamanan) sebesar 1 satuan akan mempengaruhi nilai Keputusan Pembelian sebesar 0.141 atau semakin baik Tempat maka semakin baik Keputusan Pembelian. Hal ini membuktikan hipotesis 4 tentang tempat dapat memberikan pengaruh positif terhadap keputusan pembelian baju dapat diterima. Hasil penelitian ini mendukung hasil penelitian Masyithoh (2017) yang menyatakan variabel bauran pemasaran tempat secara parsial berpengaruh terhadap keputusan pembelian madu dengan nilai $t$ hitung yang lebih besar dari t tabel. Selain itu, penelitian ini juga mendukung penelitian Marendra (2018), di mana hasil penelitian diketahui bahwa lokasi dan promosi jika diuji secara parsial berpengaruh secara signifikan terhadap keputusan pembelian dengan nilai $t$ hitung yang lebih besar dari $t$ tabel. Serta jika diuji secara bersama-sama variabel tersebut juga berpengaruh secara signifikan dengan nilai $\mathrm{F}$ hitung yang lebih besar dari $\mathrm{F}$ tabel.

Secara keseluruhan, dapat ditegaskan bahwa seluruh elemen bauran pemasaran, yaitu produk, harga, promosi, dan tempat memiliki pengaruh yang positif dan signifikan terhadap keputusan pembelian konsumen. Apabila kualitas dari aspek produk, harga, promosi, dan tempat semakin baik, maka keputusan pembelian konsumen juga akan semakin meningkat. Temuan dalam penelitian ini mengindikasikan bahwa pihak manajemen department store dituntut untuk bekerja lebih baik lagi agar mampu menarik minat beli konsumen. Hal ini sangat penting mengingat era digital saat ini dipenuhi oleh berbagai online shop dengan 
kemudahan aksesnya. Salah satu prioritas bagi pihak department store adalah bagaimana meningkatkan kepuasan konsumen. Kepuasan konsumen dapat di tingkatkan melalui peningkatan kualitas pelayanan dan produk, yakni dengan menyediakan produk baju yang up to date, berkualitas baik, dan pilihan merek-merek yang diminati konsumen. Dari aspek harga, dapat diupayakan dengan mengadakan promo dengan berbagai diskon atau hadiah yang menarik yang diadakan pada momen-momen tertentu. Dari aspek kenyamanan, department store dapat lebih memperhatikan kebersihan serta menyediakan fasilitas yang lengkap dan menarik, salah satunya yaitu dengan menyediakan kids zone atau zona bermain bagi anak kecil, serta menghadirkan spot untuk swafoto yang saat ini menjadi daya tarik bagi pengunjung. Dengan begitu, pelanggan akan merasa puas dan memberikan rekomendasi kepada orang-orang di sekitarnya untuk berbelanja di departement store.

\section{Kesimpulan}

Kesimpulan yang diperoleh dari hasil penelitian ini antara lain sebagai berikut:

1. Variabel produk berpengaruh positif dan signifikan terhadap keputusan pembelian. Produk yang mempengaruhi pembelian adalah desain baju dan merk baju. Alasannya, karena desain baju selalu up to date dan mengikuti selera konsumen, sedangkan merk baju karena berkaitan dengan gengsi konsumen dan loyalitas konsumen terhadap suatu merk.

2. Variabel harga berpengaruh positif dan signifikan terhadap keputusan pembelian. Harga yang mempengaruhi keputusan pembelian adalah harga yang dapat bersaing dan harga yang terjangkau, serta harga yang dapat memenuhi gengsi responden

3. Variabel promosi berpengaruh positif dan signifikan terhadap keputusan pembelian. Media promosi yang digunakan adalah Koran, majalah, serta radio dan televisi sesuai dengan media yang sering digunakan oleh responden dan kecenderungan asal responden mengetahui informasi promosi

4. Variabel tempat berpengaruh positif dan signifikan terhadap keputusan pembelian . Tempat yang mempengaruhi keputusan pembelian adalah yang mudah di akses, bersih dan nyaman

5. Secara simultan, variabel bauran pemasaran (produk, harga, promosi, dan tempat) terbukti berpengaruh signifikan terhadap keputusan pembelian. Adapun besar pengaruh bauran pemasaran terhadap keputusan pembelian adalah sebesar $50,3 \%$.semakin baik produk, harga, promosi, dan tempat, keputusan pembelian konsumen juga akan semakin meningkat.

Karena keterbatasan waktu dalam penelitian ini yang diteliti hanya Pengaruh Produk, Harga, Promosi dan Tempat terhadap Keputusan Pembelian. Sedangkan banyak faktorfaktor bauran pemasaran lain yang belum dibahas. Pada penelitian yang akan datang diharapkan dapat membahas faktor-faktor lain yang belum diteliti dalam penelitian ini. Mengulas permasalahan yang lebih menarik dengan subyek dan obyek,dan tempat penelitian yang tepat. Memperhatikan jumlah dan metode pengambilan sampel. Waktu penelitian yang cukup dengan variabel penelitian serta jumlah responden yang lebih banyak akan menghasilkan penelitian yang lebih baik.

Dari penelitian pasar yang telah dilakukan untuk minat masyarakat terhadap BPR yang diukur dari keberadaan BPR di Banyuwangi, pelayanan yang diberikan, profesionalitas layanan, menawarkan produk yang menarik serta kemudahan dalam akses pelayanan 
perbankan dapat disimpulkan bahwa minat masyarakat merespons sangat positif terhadap keberadaan PT BPR Artha Waringin Situbondo. Sehingga masyarakat akan menerima bila ada aktivitas perbankan di daerah tersebut untuk memberikan pelayanan perbankan.

\section{Daftar Pustaka}

Arikunto, S. (2006). Prosedur Penelitian Suatu Pendekatan Praktek. PT Rineka Cipta, Jakarta.

Amstrong dan Kotler. (2001). Prinsip-Prinsip Pemasaran. Edisi Kedelapan Jakarta: Erlangga.

Engel, J; Blackwell, R. (2004). Consumer Behavior. Dryden Press Chicago. Andi. Yogyakarta.

Lupiyoadi, Rambat. (2013). Manajemen Pemasaran Jasa. Jakarta : PT. Salemba Empat.

Mahendra, Gede. (2018). Pengaruh Bauran Pemasaran (Produk, Harga, Lokasi, Promosi) terhadap Keputusan Pembelian Konsumen Di Minimarket (Alfamart Atau Indomaret) (Studi kasus di Universitas Pamulang). Jurnal Pemasaran Kompetitif Vol 1 no 3.

Masyitoh, Dewi. (2017). Analisis Bauran Pemasaran Yang Mempengaruhi Keputusan Pembelian Madu oleh konsumen di Batu, Jawa Timur. Tesis. Fakultas Peternakan. UB Malang.

Oktavita, Riska. (2013). Pengaruh Bauran Pemasaran Terhadap Keputusan Pembelian (Survey Pada Mahasiswa Yang Mengkonsumsi Teh Botol Sostro Jurusan IImu Administrasi Bisnis Angkatan 2012/2013 Fakultas IImu Administrasi Universitas Brawijaya Malang). Jurnal Administrasi Bisnis Vol 3 No 2.

Singarimbun dan Effendi. (1995). Metode Penelitian Survey. PT Pustaka. LP3ES. Jakarta.

Soedjatna T.D.T, Sudaryanto dan R. Sayuti. (1994). Estimasi Parameter Permintaan Beberapa Komoditas Peternakan di Jawa. Jurnal Penelitian Peternakan Indonesia.

Sugiyono. (2008). Metode Penelitian Pendidikan (Pendidikan Kualitatif, kualitatif dan R \& D). Bandung : Alfabeta.

Swastha Basu DH dan Irawan. (2002). Manajemen Pemasaran Modern. Yogyakarta: Liberty.

Tumbel, Lenny Altje dan Van Rate, Paulina. (2015). Pengaruh Bauran pemasaran terhadap Keputusan Pembelian Di Pasar Tradisional Di Kota Manado. Jurnal LPPM Bidang EkoSosBudKum Volume 2 No 2.

Yang, Zhilin \& Peterson, Robin T. (2004). Customer Perceived Value, Satisfaction, and Loyalty: The Role of Switching Cost. Psychology \& Marketing, Vol. 21, No. 10: 799822.

Zeithaml. V. A. \& Bitner, M. J. (2003). Service Marketing: Integated Costumer Focus Across The Firm. New York: Mc Graw Hill Companies. 